\title{
Research on the Innovation and Entrepreneurship Education Mode in Colleges and Universities Based on Entrepreneurial Ecosystem Theory
}

\author{
Zhipeng $\mathrm{Cao}^{1}$ \\ Mei Zhou ${ }^{2}$ \\ Changshu Institute of Technology \\ Changshu Institute of Technology
}

\begin{abstract}
Innovation and entrepreneurship education has become an educational form and concept in the era of knowledge economy and it is an inevitable trend in college education to extensively promote innovation and entrepreneurship education in colleges and universities. Also, it is an inevitable demand for the talent cultivation of higher education to constantly promote and upgrade the quality of innovation and entrepreneurship education in colleges and universities. This paper discusses the development of innovation and entrepreneurship education in China's colleges and universities through questionnaires and it is found that the current situation for innovation and entrepreneurship education in colleges and universities is low awareness, relatively weak consciousness and the incomplete curriculum system. At the same time, based on the entrepreneurial ecosystem theory, a new innovative and entrepreneurial education model is established, which embeds innovation and entrepreneurship education into the innovation and entrepreneurship ecosystem. The practice proves that this model has a good effect on the cultivation of innovative and entrepreneurial talents, which is of great theoretical and practical significance for the continuous improvement of education mode.
\end{abstract}

\section{Keywords}

Entrepreneurial Ecosystem Theory • Innovative Education in Colleges and Universities • Entrepreneurship Education • Mode Research

\footnotetext{
${ }^{1}$ Correspondence to: Zhipeng Cao (MA), Changshu Institute of Technology, College of Business and Management, Department of Finance, Changshu 215500, China. Email: zhipeng_rrr@ hotmail.com

2. Hangshu Institute of Technology, College of Business and Management, Department of Finance, Changshu 215500, China. Email: cszhoumei123@sina.com
} 
Promoting the continuous and in-depth development of innovation and entrepreneurship education in colleges and universities is the practical need of the country to promote economic development. At the same time, it is also an important measure to promote the comprehensive education reform of colleges and universities and improve the quality of innovation and entrepreneurship of graduates. At present, innovation and entrepreneurship education has become an educational form and concept in the era of knowledge economy and it has become the mainstream of social development to extensively develop innovation and entrepreneurship education in colleges and universities (Harkema \& Schout, 2010). In recent years, the innovation and entrepreneurship education of colleges and universities in China has developed rapidly and achieved good results. The innovative spirit and entrepreneurial consciousness of college students have been promoted continuously and it has gradually developed into an important part of talent cultivation in colleges and universities. How to further strengthen the innovation and entrepreneurship education in colleges and universities and focus on improving the innovative and entrepreneurial ability of college students is not only the inevitable requirement of economic and social development, but the inevitable demand for the talent cultivation of higher education (Mustar, 2009).

At present, there are many drawbacks and limitations in the development of innovation and entrepreneurship education in colleges and universities. There is relatively large amount of theoretical teaching while small amount of practical operation, which is not conducive to the improvement of the quality of innovation and entrepreneurship education in colleges and universities and the cultivation of innovative and entrepreneurial talents (Niccum, Sarker \& Wolf, 2017). Based on the entrepreneurial ecosystem theory, this paper establishes a new mode of innovation and entrepreneurship education to embed innovation and entrepreneurship education into the innovation and entrepreneurship ecosystem, which is of great theoretical and practical significance for promoting the continuous improvement of education mode.

\section{Introduction to Entrepreneurial Ecosystem Theory}

\section{Entrepreneurial ecosystem at state level}

In the 1990s, American scholar Ezkoweitz created a three-helix structure to study the new interaction between government, industry, and universities in the era of knowledge economy. Government, enterprises and universities are the three main factors in the innovation system environment in the knowledge-based economy society. They are linked to each other according to the specific needs of the market to form three forces and the interactional triple helix relationship (Mok, 2015). At present, the application of the triple helix structure in higher education is mainly concentrated in entrepreneurial universities. 


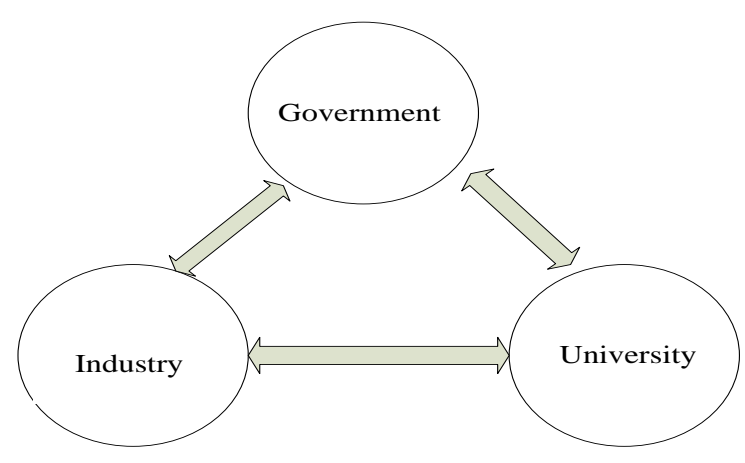

Figure 1. Innovation and entrepreneurship ecosystem: three helix structure.

\section{Entrepreneurial ecosystem at regional level}

To achieve entrepreneurial success, it is necessary to understand how to build a dynamic market for talent, capital and creativity (Radharamanan \& Juang, 2012). In the entrepreneurial ecosystem at regional level, the structure and flow of high mobility and connectivity are established for talent, capital and creativity, as shown in Figure 2.

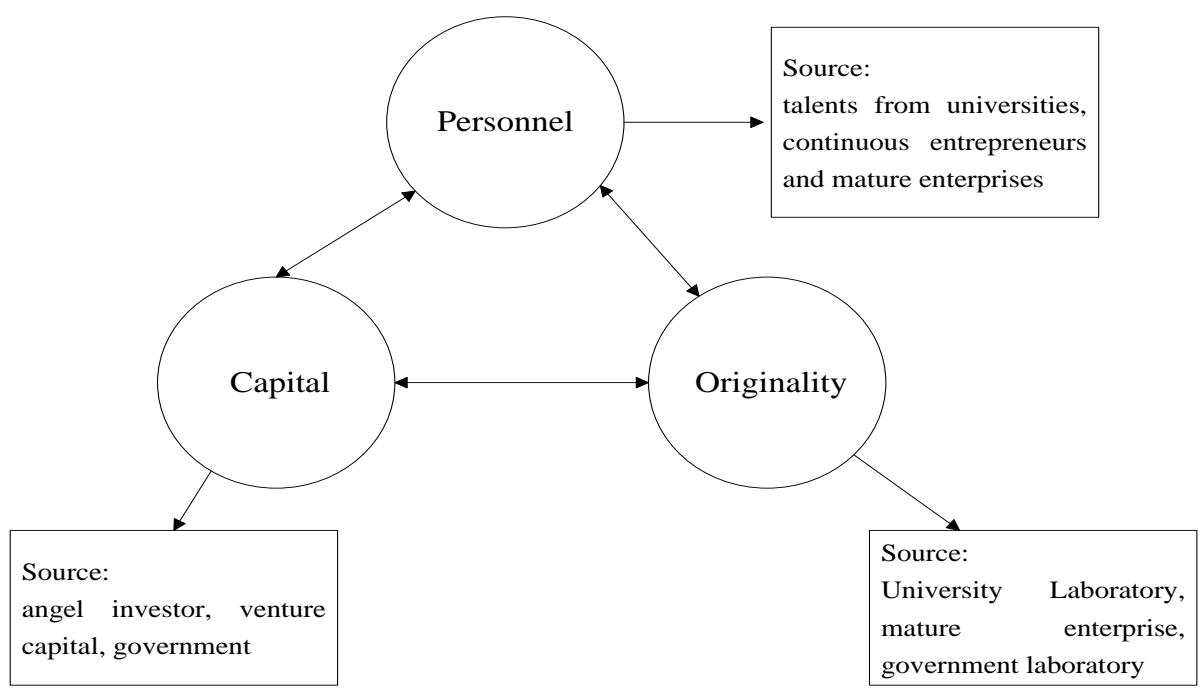

Figure 2. Entrepreneurial ecosystem at the regional level.

\section{Entrepreneurial ecosystem at enterprise level}

American entrepreneurial expert Thomas believes that the most important driving factors in the entrepreneurial process are resources, opportunities and teams. Based on these three factors, he has established a model, as shown in Figure 3: 


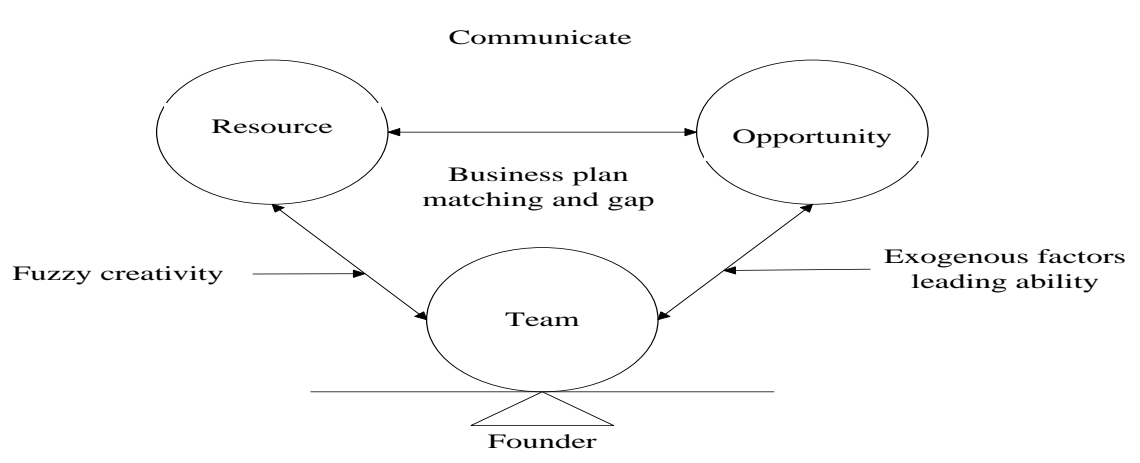

Figure 3. Entrepreneurial ecosystem at the enterprise level.

A relatively successful entrepreneurial process is the constant balance process among these three driving factors. Entrepreneurs need to find opportunities in the uncertain external environment, use external resources comprehensively and build effective teams to achieve entrepreneurial success. In this process, it is difficult to achieve a complete match among these three driving factors. However, as long as the dynamic balance is achieved, the entrepreneurship can be promoted (Wang \& Kleppe, 2001).

Based on the above three levels of entrepreneurial ecosystem, a comprehensive entrepreneurial ecosystem model can be obtained, as shown in Figure 4.

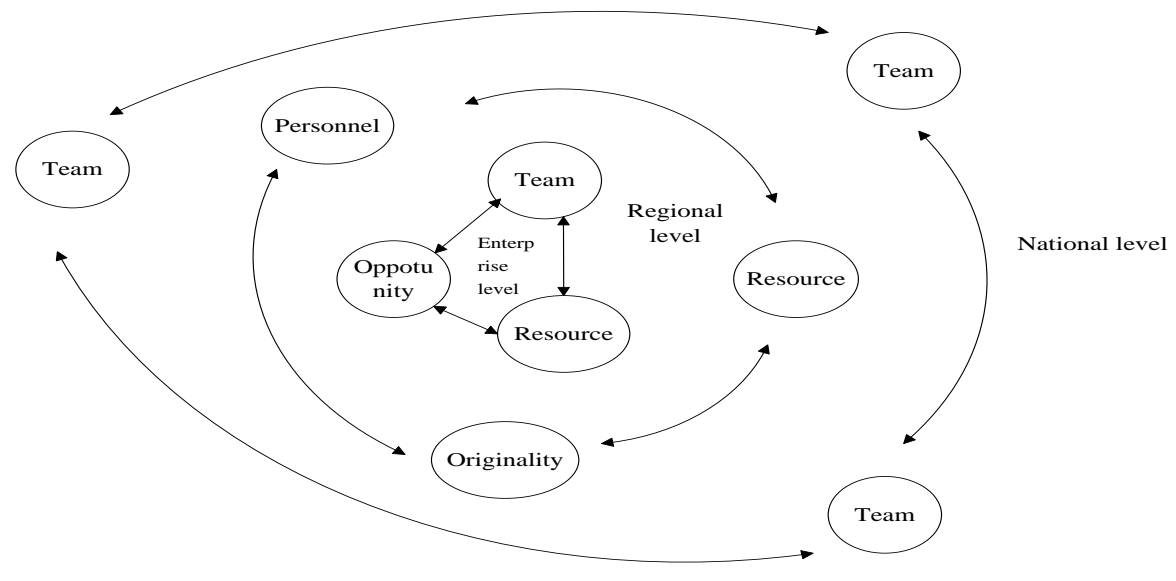

Figure 4. Integrated entrepreneurial ecosystem.

It can be found from Figure 4 that the entrepreneurial ecosystem at the national, regional and enterprise levels are not independent and separated, but can form a model to promote the development of each other, thus promoting the continuous development of entrepreneurial ecosystem. 


\section{Discussion on the Development of Innovation and Entrepreneurship Education in Colleges and Universities}

In order to have a more comprehensive and accurate understanding of the current situation of the development of innovation and entrepreneurship education in colleges and universities, the author conducts questionnaire survey on some college students in Heilongjiang Province. The number of questionnaires distributed is 500. Altogether 490 questionnaires are collected and the number of valid questionnaires is 485 . The summarization and analysis of the result of questionnaires can reflect the development of innovation and entrepreneurship education in China' colleges and universities to a certain extent.

\section{Low awareness of innovation and entrepreneurship education}

It can be found from Figure 5 that more than $60 \%$ of college students do not understand innovation and entrepreneurship education, indicating that the awareness of college students for innovation and entrepreneurship education is still relatively low and that many people do not really understand innovation and entrepreneurship education.

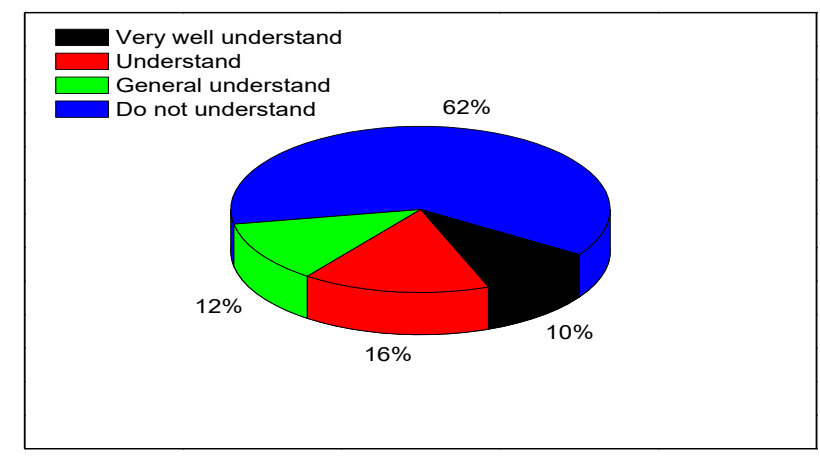

Figure 5. Statistical chart of Students' understanding of innovation and Entrepreneurship Education.

\section{Weak consciousness of innovation and entrepreneurship education}

Table 1 shows the emphasis situation on innovation and entrepreneurship education in colleges and universities. It can be seen that $65 \%$ of college students believe that the school does not attach importance to innovation and entrepreneurship education, which indicates that colleges and universities have not paid enough attention to innovation and entrepreneurship education and that the consciousness of innovation and entrepreneurship education is weak.

Table 1

Statistics on Importance of Innovation and Entrepreneurship Education in Colleges and Universities

\begin{tabular}{lcccc}
\hline $\begin{array}{l}\text { Degree of } \\
\text { attention }\end{array}$ & $\begin{array}{c}\text { Make much account } \\
\text { of }\end{array}$ & Importance & $\begin{array}{c}\text { General } \\
\text { attention }\end{array}$ & $\begin{array}{c}\text { Do not pay attention } \\
\text { to }\end{array}$ \\
\hline Occupation ratio & $9 \%$ & $5 \%$ & $21 \%$ & $65 \%$ \\
\hline
\end{tabular}


In terms of the importance of innovation and entrepreneurship education, although more than half of college students believe that innovation and entrepreneurship education is important, the overall awareness of the importance of innovation and entrepreneurship education is not high. Especially for girls, $42 \%$ of girls consider that innovation and entrepreneurship education is not important (see Table 2 for details), which shows that the awareness of girls for the importance of innovation and entrepreneurship education is weak.

Table 2

Statistical Table of College Students' Awareness of the Importance of Innovation and Entrepreneurship Education

\begin{tabular}{llcccc}
\hline Importance & & Very important & Important & General important & Not important \\
Occupation ratio & Male & $16 \%$ & $18 \%$ & $36 \%$ & $28 \%$ \\
& Female & $13 \%$ & $10 \%$ & $42 \%$ & $42 \%$ \\
\hline
\end{tabular}

Through the above result analysis, it can be found that college students do not pay enough attention to innovation and entrepreneurship education and the awareness of innovation and entrepreneurship education is very weak.

\section{Incomplete innovative entrepreneurship education curriculum system}

Different from traditional quality education, innovation and entrepreneurship education needs to stimulate and cultivate the awareness and ability of college students for innovation and entrepreneurship through massive practices (Servoss, et al., 2017). However, it can be seen through the investigation and analysis of the implementation form of innovation and entrepreneurship education in colleges and universities that the proportion of classroom teaching and expert lecture is relatively large, while the proportion of innovation and entrepreneurship education practice is small (see Figure 6 for details), which reflects that the current form of curriculum system of innovation and entrepreneurship education is relatively simple and incomplete.

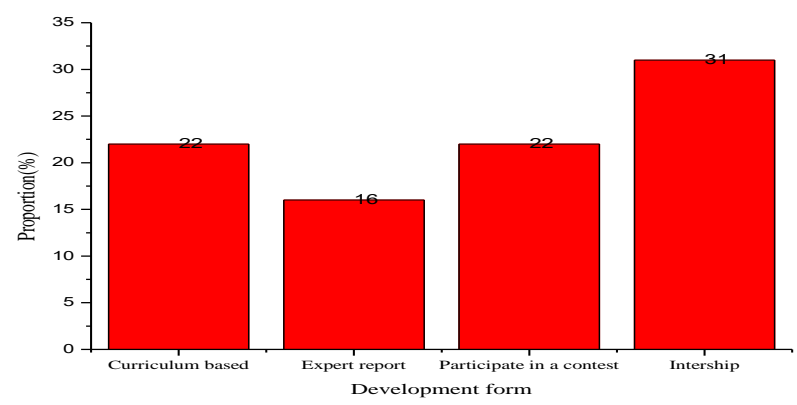

Figure 6. Development form statistical chart of innovation and entrepreneurship education.

\section{Innovation and Entrepreneurship Education Mode Based on Entrepreneurial Ecosystem}

In December 2017, Heilongiiang University established the "Innovation and Entrepreneurship Institute", the purpose of which was mainly to provide service for the innovation and entrepreneurship education of the 
school (Matthew, Jeffrey, William, Batia \& Michael, 2012). Under the impetus of the Institute, the school regularly invites successful entrepreneurs to deliver lectures at the school and has established cooperative relationship with the Entrepreneurship Centre and the Management Committee of the Technical Development Zone in Harbin City, which has established the bridge of communication for the cooperation between the government, enterprises and universities.

Under the strong impetus of innovation and entrepreneurship institute, the school held the "Innovative Enterprise Business Plan Roadshow Competition”. It has attracted the extensive participation form a large number of venture capital enterprises and college students, embedded the innovation and entrepreneurship education of the school into the entrepreneurial ecosystem and become a perfect example of the combination of government, enterprises and universities (Finardi, 2013). The specific process is:

First of all, the Innovation and Entrepreneurship Institute will actively recommend this project to the government. The government will provide a list of innovative enterprises, which are the key objects for the internship and service of students. Secondly, students choose the enterprises independently and write industry reports for the enterprise to attract the attention of founders. If they are recognized, they may get an internship opportunity. Next, enterprises and students reach the cooperation intention and students can enter the innovative enterprise for internships, and deep research, so that they can use professional knowledge to complete more indepth survey reports of enterprises. Students can feedback these reports to enterprises, which is conducive to their future development. On this basis, students can work on business plans and participate in roadshows (Schulman \& Lyons, 2013). During the road show, the school will invite renowned venture capital experts to serve as judges, who will judge the rationality and feasibility of the business plan from a professional perspective. These judges will also complete the scoring and ranking and offer good suggestions to students. During the roadshow, a large number of students obtain valuable practical opportunities and some outstanding students eventually enter the enterprise where they have worded as intern after graduation; many enterprises also take the opportunity to obtain the capital from venture capital institutions. After acquiring the capital, the enterprise has made great progress. It can be said that this mode has established a good entrepreneurial ecosystem and achieved good results.

\section{Conclusion}

This paper analyzes the current situation of innovation and entrepreneurship education in China's colleges and universities through questionnaires and establishes a new innovation and entrepreneurship education mode based on the entrepreneurial ecosystem theory. The research conclusions are as follow:

(1) Through the questionnaire survey method, it is found that the current situation for innovation and entrepreneurship education in colleges and universities is low awareness, relatively weak consciousness and the incomplete curriculum system. 
(2) The innovation and entrepreneurship education is embedded into the innovation and entrepreneurship ecosystem and a new innovation and entrepreneurship education mode is established. Through concrete practice, this mode is proved to have a good effect on the cultivation of innovative and entrepreneurial talents.

\section{References}

Finardi, U. (2013). Clustering research, education, and entrepreneurship: nanotech innovation at minatec in $\begin{array}{llll}\text { grenoble. } & \text { Research-Technology } & \text { Management, } & \text { 56(56), }\end{array}$ http://dx.doi.org/10.5437/08956308x5601040

Harkema, S. J. M., \& Schout, H. (2010). Incorporating student-centred learning in innovation and entrepreneurship education. European Journal of Education, 43(4), 513-526. http://dx.doi.org/10.1111/j.1465-3435.2008.00372.x

Matthew, J. M., Jeffrey, S. S., William, J. B., Batia, M. W., \& Michael, W. K. (2012). Exploring innovative entrepreneurship and its ties to higher educational experiences. Research in Higher Education, 53(8), 831859. http://dx.doi.org/10.1007/s11162-012-9258-3

Mok, K. H. (2015). The quest for global competitiveness: promotion of innovation and entrepreneurial universities in Singapore. Higher Education Policy, 28(1), 91-106. http://dx.doi.org/10.1057/hep.2014.30

Mustar, P. (2009).Technology management education: innovation and entrepreneurship at mines paristech, a leading french engineering school. Academy of Management Learning \& Education, 8(3), 418-425. http://dx.doi.org/10.5465/amle.2009.44287940

Niccum, B. A., Sarker, A., \& Wolf, S. J. (2017). Innovation and entrepreneurship programs in us medical education: a landscape review and thematic analysis. Medical Education Online, 22(1), 1360722. http://dx.doi.org/10.1080/10872981.2017.1360722

Radharamanan, R., \& Juang, J. N. (2012). Innovation and entrepreneurship in engineering education at muse. Journal of the Chinese Institute of Engineers, 35(1), 25-36. http://dx.doi.org/10.1080/02533839.2012.624797

Schulman, S. A., \& Lyons, T. S. (2013). New frontiers of the innovation economy and education. Entrepreneurship Research Journal, 4(1), 137-146. http://dx.doi.org/10.1515/erj-2013-0075

Servoss, J., Chang, C., Olson, D., Ward, K. R., Mulholland, M. W., \& Cohen, M. S. (2018). The surgery innovation and entrepreneurship development program (SIEDP): An experiential learning program for surgery faculty to ideate and implement innovations in health care. Journal of Surgical Education, 75(4), 935-941.http://dx.doi.org/10.1016/j.jsurg.2017.09.017

Wang, E. L., \& Kleppe, J. A. (2001). Teaching invention, innovation, and entrepreneurship in engineering. Journal of Engineering Education, 90(4), 565-570. http://dx.doi.org/10.1002/j.2168-9830.2001.tb00640.x 